\title{
Inhibition of Protein Phosphatase 1 Stimulates Secretion of Alzheimer Amyloid Precursor Protein
}

\author{
Edgar F. da Cruz e Silva, Odete A. B. da Cruz e Silva, \\ Cássia Thais B. V. Zaia, and Paul Greengard \\ The Rockefeller University, Laboratory of Molecular and Cellular \\ Neuroscience, New York, New York, U.S.A.
}

\begin{abstract}
Background: Aberrant metabolism of the Alzheimer amyloid precursor protein (APP) or its amyloidogenic A $\beta$ fragment is thought to be centrally involved in Alzheimer's disease. Nonamyloidogenic processing of APP involves its cleavage within the $A \beta$ domain by a protease, termed $\alpha$-secretase, and release of the large extracellular domain, termed APP ${ }^{\mathrm{S}}$. Secretion of $\mathrm{APP}^{\mathrm{S}}$ can be stimulated by phorbol esters, activators of protein kinase $C$, with concurrent inhibition of $A \beta$ production. While the role of protein kinases on APP metabolism has been investigated, considerably less effort has been devoted to elucidating the role played by protein phosphatases. Okadaic acid, a protein phosphatase inhibitor, has been shown to stimulate secretion of $\mathrm{APP}^{\mathrm{S}}$, but the identity of the phosphatase involved has not been investigated.

Materials and Methods: The secretion of APP ${ }^{S}$ from COS-1 cells was measured in the absence or presence of various doses of serine/threonine-specific phosphatase inhibitors. Quantitation of the derived $\mathrm{IC}_{50}$ values was used to determine the identity of the phosphatase involved in the control of APP secretion.
\end{abstract}

Results: The availability of protein phosphatase inhibitors with different relative potencies against the different types of serine/threonine-specific protein phosphatase allowed us to examine which of the four known types of protein phosphatase might be involved in the regulation of APP secretion. Both okadaic acid and calyculin A stimulated the secretion of APP from COS-1 cells in a dose-dependent manner. The half-maximal dose for stimulation of APP secretion was approximately 100-fold higher with okadaic acid than with calyculin A.

Conclusions: The nearly 100 -fold difference in the observed $\mathrm{IC}_{50}$ values for okadaic acid and calyculin A implicates a type 1 protein phosphatase in the control of $\mathrm{APP}^{\mathrm{S}}$ production. Protein phosphatase 1 (PPl) is known to be highly expressed in adult mammalian brain, both in neurons and glia. The identification of a specific phosphatase type in the control of APP secretion opens new avenues to the development of rational therapeutic intervention strategies aimed at the prevention and/or treatment of Alzheimer's Disease.

\section{INTRODUCTION}

Alzheimer's disease $(\mathrm{AD})$ is the most common of the neurodegenerative diseases, probably affecting more than $50 \%$ of individuals over the age of 80. Central to the pathology of the disease is the formation of senile plaques in the brains of affected individuals. The amyloid core of these plaques is comprised largely of a small 39-43 amino acid peptide ( 1 ), termed $A \beta$, derived from the Alzheimer amyloid precursor protein (APP). APP can also be processed via a nonamyloido-

Address correspondence and reprint requests to: Edgar F. da Cruz e Silva, The Rockefeller University, Box 296, 1230 York Avenue, New York, NY 10021, U.S.A. genic pathway by a protease ( $\alpha$-secretase) that cleaves APP within the $A \beta$ domain and releases the large extracellular domain $\left(\mathrm{APP}^{\mathrm{S}}\right)$.

Previous work has shown that treatment of a variety of cells with phorbol esters stimulates the release of $\mathrm{APP}^{\mathrm{S}}$, presumably via protein kinase $\mathrm{C}$-mediated phosphorylation of a target protein (2-5). A similar effect can be obtained using okadaic acid (an inhibitor of serine/threoninespecific protein phosphatases), possibly via increased phosphorylation of the same target protein due to phosphatase inhibition. In addition, protein kinase $C$ (PKC) was shown to phosphorylate the cytoplasmic domain of APP $(6,7)$ at a 
site that is also phosphorylated in vivo (M. Oishi and P. Greengard, unpublished observations). However, $\mathrm{APP}^{\mathrm{S}}$ secretion can still be stimulated by phorbol esters or okadaic acid in the absence of the cytoplasmic domain of APP $(4,5)$. Thus, although the identity of the target protein has not been elucidated, it is unlikely to be the APP protein itself. Phorbol ester stimulation of APP ${ }^{S}$ secretion implicates PKC in APP processing. Likewise, the stimulation of $\mathrm{APP}^{\mathrm{S}}$ secretion by okadaic acid implicates a phosphatase. However, the question of which type of serine/threonine-specific protein phosphatase is involved in APP secretion has not been addressed previously.

Four major types of serine/threonine-specific protein phosphatase have been identified in eukaryotic cells (termed 1, 2A, 2B, and 2C), which can be distinguished by a variety of biochemical and enzymatic properties (reviewed in Ref. 8). Of the four types of protein phosphatases, PP1 and PP2A exhibit broad and overlapping substrate specificities in vitro, accounting for almost all measurable activity towards a variety of phosphoproteins regulating cellular processes. PP2B (also known as calcineurin) is active on a much more restricted range of substrates, and PP2C is structurally unrelated to the other types. Recent recombinant DNA approaches identified the existence of several isoforms for each phosphatase type and revealed that types 1, 2A, and $2 \mathrm{~B}$ belong to a gene family distinct from that of phosphatase 2C. A number of "novel" phosphatases have also been identified in a variety of organisms, the first of which was termed protein phosphatase $X(9)$.

A variety of compounds is now available capable of specifically inhibiting serine/threoninespecific protein phosphatases. Two of the best characterized are okadaic acid and calyculin A (10). Since they readily enter intact cells, they can be used to determine which phosphatase is active in a particular process by virtue of their different relative potencies against the various phosphatase types. In this study we have used them to identify the protein phosphatase involved in the control of $\mathrm{APP}^{\mathrm{S}}$ production. The data presented here were the subject of a preliminary report (11).

\section{MATERIALS AND METHODS}

\section{Materials}

Calyculin A, okadaic acid, PDBu (phorbol 12,13dibutyrate), Dulbecco's modified Eagle's medium
(DMEM), and fetal bovine serum were obtained from Life Technologies Inc. (Gaithersburg, MD, U.S.A.). Cantharidin was purchased from Sigma Chemical Co. (St. Louis, MO, U.S.A.). Murine monoclonal antibody $22 \mathrm{C} 11$, prepared against the amino terminus of APP (12), was purchased from Boehringer Mannheim Corporation (Indianapolis, IN, U.S.A.). Murine monoclonal antibody $6 \mathrm{E} 10$, whose epitope is located within residues $1-17$ of $A \beta$, was obtained from Drs. H. M. Wisniewski and K. S. Kim (New York State Institute for Basic Research in Developmental Disabilities).

\section{Cell Culture, Drug Treatment, and Detection of Secreted APP}

COS-1 cells were grown in DMEM supplemented with $10 \%$ fetal bovine serum at $37^{\circ} \mathrm{C}$ and $5 \%$ $\mathrm{CO}_{2}$. The cells were subcultured in triplicate into six-well plates and grown to confluency. After two washes with phosphate buffered saline, the cells were incubated in the absence or presence of varying concentrations of either PDBu (for 60 $\mathrm{min}$ ) or the indicated phosphatase inhibitors (for $90 \mathrm{~min}$ ). When a combination of drugs was used, the time of exposure was kept to $60 \mathrm{~min}$. All drugs were prepared by diluting the stock solutions into serum-free DMEM. Following incubation as described above, the conditioned medium was collected into tubes containing SDS ( $1 \%$ final concentration), and boiled for $5 \mathrm{~min}$. The samples, normalized for protein content (13), were subjected to SDS-polyacrylamide gel electrophoresis on $7.5 \%$ gels (14). The separated proteins were then electrophoretically transferred onto nitrocellulose and probed with antibodies $22 \mathrm{Cll}$ or $6 \mathrm{E} 10$, as described in the figure legends. The immunoblots were washed and then incubated successively with rabbit antimouse IgG (Cappel, Durham, NC) and ${ }^{125}$ I-protein A (Amersham, Arlington Heights, IL, U.S.A.). Immunoreactive bands were detected by autoradiography and quantitated using a PhosphorImager (Molecular Dynamics, Sunnyvale, CA, U.S.A.).

\section{RESULTS}

Several previous studies showed that APP secretion can be stimulated in a variety of cells using phorbol esters. Indeed, in a previous report we demonstrated that PDBu (phorbol 12,13-dibutyrate) could stimulate the secretion of both en- 


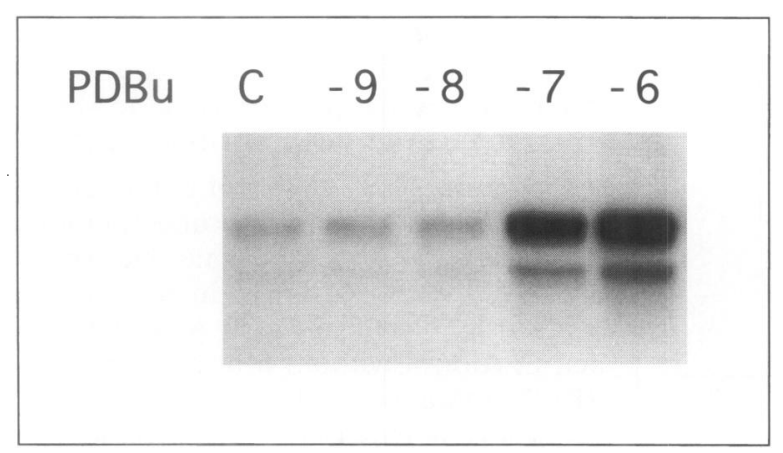

FIG. 1. Stimulation of APP ${ }^{s}$ production from COS-1 cells in response to PDBu treatment

Cells were treated with the PDBu concentrations indicated $\left(10^{-9}-10^{-6} \mathrm{M}\right)$, and the $\mathrm{APP}^{\mathrm{S}}$ released into the medium was quantitated by immunoblotting with antibody $22 \mathrm{Cl1}$. C, control without PDBu.

dogenous APP and transfected wild-type and mutant APP expressed in COS-1 cells (4). In the present study, we have further characterized the control of secretion of endogenous APP from COS-1 cells in response to agents capable of modulating the state of phosphorylation of intracellular proteins. PDBu treatment of COS-1 cells was shown to stimulate secretion of endogenous APP in a dose-dependent manner (Fig. 1). The concentration of PDBu required for half-maximal effect $\left(\mathrm{EC}_{50}\right)$ was approximately $50 \mathrm{nM}$ (Table 1). We have previously reported the $\mathrm{EC}_{50}$ value for $\mathrm{PDBu}$-stimulated processing of APP to be $17 \mathrm{nM}$ in PC12 cells, as measured by following the disappearance of mature intracellular APP using an antibody whose epitope lies in the C-terminal intracellular domain of APP (15). Thus, there is reasonable agreement between the two experimental systems, even though different parameters were measured and different cell types were used.

APP secretion can be stimulated not only by activators of $\mathrm{PKC}$, such as PDBu, but also by inhibitors of serine/threonine-specific protein phosphatases. Thus, okadaic acid was shown to stimulate APP secretion in PC12 cells (2) and in COS-1 cells (4). However, the identity of the phosphatase targeted by such inhibitors was not elucidated. The availability of other naturally occurring compounds that are cell permeable and act as specific inhibitors of certain of the serine/ threonine-specific protein phosphatases has allowed us to investigate the nature of the phosphatase involved in the control of APP secretion. Both okadaic acid and calyculin A stimulated the
TABLE 1. Concentration of test substance required to achieve half-maximal secretion of APPs

\begin{tabular}{lrr}
\hline & \multicolumn{2}{c}{$\mathrm{EC}_{50}(\mathrm{nM})$} \\
\cline { 2 - 3 } Test Substance & $22 \mathrm{Cl1}$ & 6E10 \\
\hline Okadaic Acid & 80 & 110 \\
Calyculin A & 1 & 1 \\
Cantharidin & 500 & ND \\
PDBu & 54 & ND \\
\hline
\end{tabular}

The range of concentrations used for each test substance was as follows: $10^{-10}-10^{-6} \mathrm{M}$ okadaic acid, $10^{-11}-10^{-7} \mathrm{M}$ calyculin A, $10^{-9}-10^{-5} \mathrm{M}$ cantharidin, and $10^{-10}-10^{-6} \mathrm{M}$ PDBu. The amount of APP secreted into the medium was expressed as a percentage of the maximal amount, as exemplified in Fig. 2B. Immunoreactive bands were quantitated by immunoblotting using a PhosphorImager. The drug concentration required to achieve half-maximal secretion of APP from COS-1 cells $\left(\mathrm{EC}_{50}\right.$ ) was calculated from the average results obtained in several experiments, each performed in triplicate, and are tabulated above. ND, not determined.

production of $\mathrm{APP}^{\mathrm{S}}$ from COS- 1 cells in a dosedependent manner (Fig. 2A). Quantitation of the results from several dose-response experiments using antibody $22 \mathrm{Cl} 1$ yielded average $\mathrm{EC}_{50}$ values of 80 and $\mathbf{l n M}$ for okadaic acid and calyculin A, respectively (Fig. 2B, Table 1). Since antibody $22 \mathrm{Cll}$ has been reported to cross-react with APP-related proteins $(16,17)$ and does not differentiate between $\alpha$-secretase and $\beta$-secretase cleaved APP , we sought to confirm and extend our results using a more specific antibody. Thus, using antibody $6 \mathrm{E} 10$, which specifically recognizes APP ${ }^{S}$ produced by the $\alpha$-secretase pathway, we obtained $\mathrm{EC}_{50}$ values of 110 and $1 \mathrm{nM}$ for okadaic acid and calyculin A, respectively (Fig. 3, Table 1). Given the approximately 100 -fold difference in the calculated $\mathrm{EC}_{50}$ values for okadaic acid and calyculin A, these results identify protein phosphatase 1 (PPl) as being the target of the phosphatase inhibitors used (see Discussion below), and therefore implicate it in the control of APP cleavage and secretion.

Cantharidin, isolated from blister beetles, is a recently described phosphatase inhibitor $(18,19)$ thought to be the active ingredient in the purported aphrodisiac, "Spanish fly". Cantharidin, like okadaic acid and calyculin A, was also capable of stimulating $\mathrm{APP}^{\mathrm{S}}$ production from COS-1 


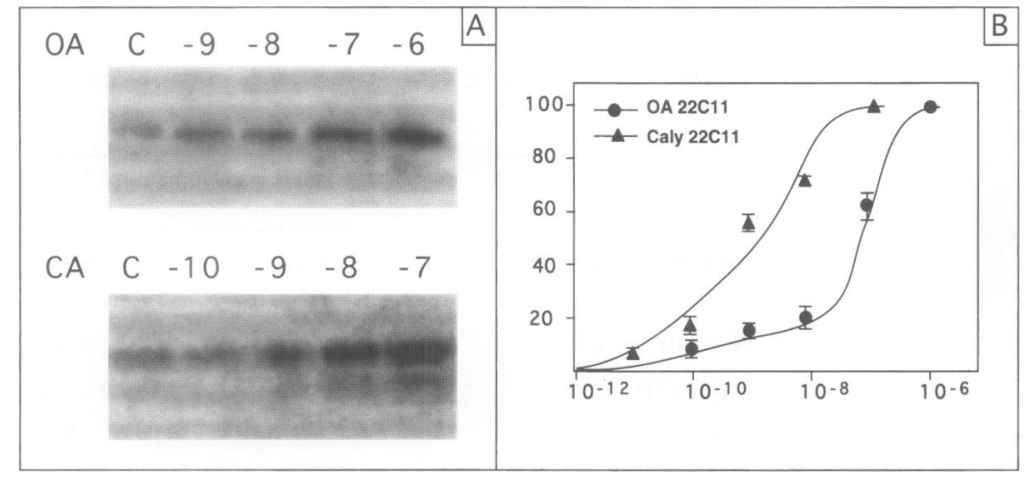

FIG. 2. Stimulation of $\mathrm{APP}^{\mathrm{s}}$ production from COS-1 cells, in response to treatment with phosphatase inhibitors, measured with antibody $22 \mathrm{Cl} 1$

(A) Immunoblot analysis of COS-1 cells treated with the indicated concentrations of OA $\left(10^{-9}-10^{-6} \mathrm{M}\right.$ okadaic acid) or CA $\left(10^{-10}-10^{-7} \mathrm{M}\right.$ calyculin $\mathrm{A}$; higher concentrations of calyculin A were toxic). C, control without drug treatment. (B) Quantitation of the dose response from several experiments. The values plotted are the mean \pm SEM. cells in a dose-dependent manner (Fig. 4A). In this case, the calculated $\mathrm{EC}_{50}$ was approximately $500 \mathrm{nM}$ (Table 1). The higher $\mathrm{EC}_{50}$ value obtained for cantharidin in comparison with okadaic acid and calyculin $\mathrm{A}$ is in agreement with their relative in vitro phosphatase inhibitory potencies (Ref. 19 and E. F. da Cruz e Silva et al., manuscript in preparation). Using submaximal doses of PDBu $\left(10^{-8} \mathrm{M}\right)$ and cantharidin $\left(10^{-7}\right)$, an additive effect was measured (Fig. 4B); the use of maximally effective doses of both did not

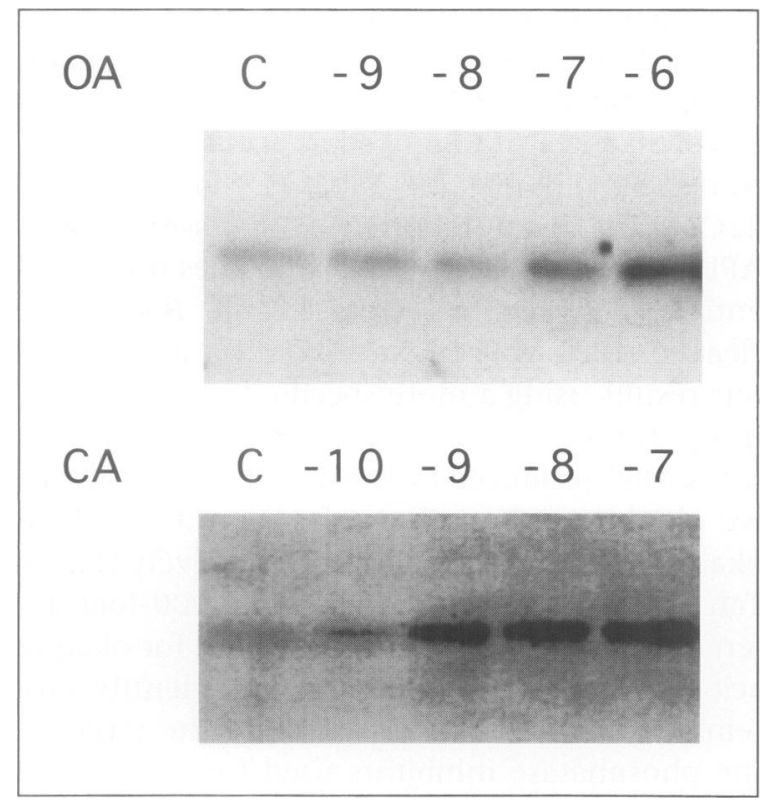

FIG. 3. Stimulation of APPS production from COS- 1 cells, in response to treatment with phosphatase inhibitors, measured with antibody $6 \mathrm{E} 10$

Cells were treated with the indicated concentrations of OA $\left(10^{-9}-10^{-6} \mathrm{M}\right.$ okadaic acid) or CA $\left(10^{-10}\right.$ $10^{-7} \mathrm{M}$ calyculin A). C, control without drug treatment. result in further stimulation of $\mathrm{APP}^{\mathrm{S}}$ production beyond the levels achieved with either drug alone (Fig. 4B and data not shown). These results are consistent with phorbol esters and phosphatase inhibitors affecting the state of phosphorylation of the same target protein via the activation of PKC or the inhibition of PPI.

The evidence presented above indicating that $\mathrm{PPl}$ regulates $\mathrm{APP}^{\mathrm{S}}$ production in COS-1

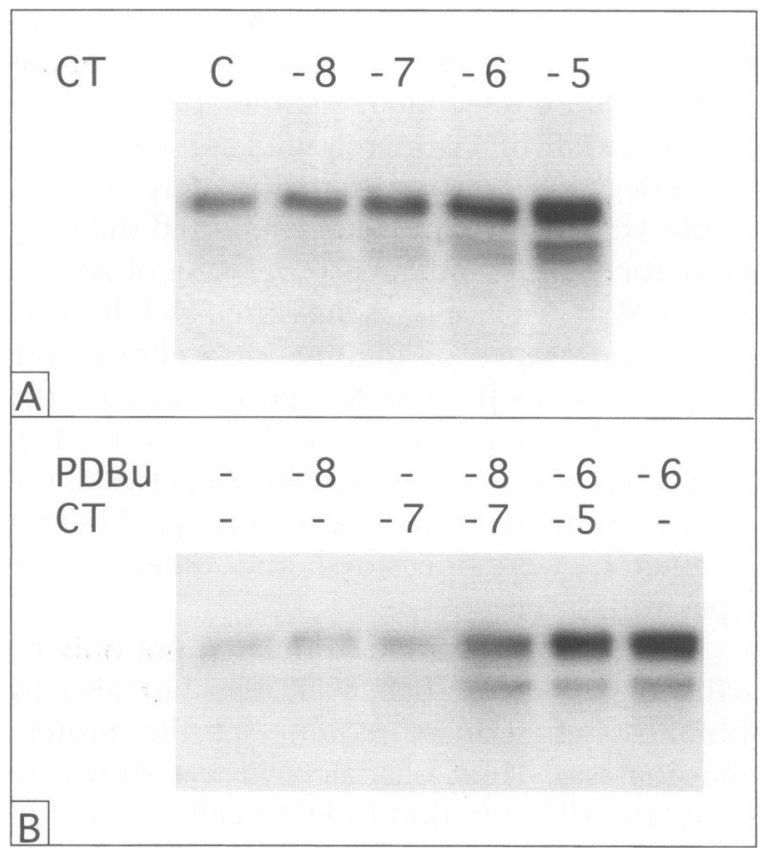

FIG. 4. Cantharidin stimulation of APP $^{S}$ production from COS-1 cells as measured with antibody $22 \mathrm{C} 11$

(A) Immunoblot analysis of the dose response using the indicated concentrations of cantharidin $\left(10^{-8}\right.$ $\left.10^{-5} \mathrm{M}\right)$. C, control without cantharidin treatment. (B) Immunoblot analysis of APP ${ }^{\mathrm{s}}$ production in response to the indicated concentrations of PDBu and cantharidin (CT). - , absence of drug. 
cells led us to examine these cells for the expression of PP1. The mammalian genome is known to contain at least three different genes encoding PPl catalytic subunits, namely, $\operatorname{PPl} \alpha, \operatorname{PP} 1 \beta$, and PPl $\gamma(20,21)$. PPl $\gamma$ is known to undergo tissuespecific alternative splicing to generate two proteins differing solely at their extreme carboxyl termini. One of these, $\operatorname{PPl} \gamma_{1}$, is ubiquitously expressed in most tissues, whereas the other isoform, PPl $\gamma_{2}$, is thought to be testis specific $(20,22)$. Previously described isoform-specific antibodies $(22,23)$ detected both PPl $\alpha$ and PPl $\gamma_{1}$ in COS-1 cells (data not shown).

\section{DISCUSSION}

The availability of several phosphatase inhibitors with different potencies against the various types of phosphatase allowed us to investigate the identity of the phosphatase involved in the control of APP secretion. Both okadaic acid and calyculin $\mathrm{A}$ are potent inhibitors of protein phosphatase types 1 and $2 \mathrm{~A}$, whereas PP2B is only inhibited at much higher concentrations and PP2C is essentially resistant to these compounds. However, while calyculin A is equally potent in vitro against purified PPI and PP2A $\left(\mathrm{IC}_{50}=1-2\right.$ $\mathrm{nM}$ ), okadaic acid inhibits PPl with an $\mathrm{IC}_{50}$ of 10-100 nM and PP2A with an $\mathrm{IC}_{50}$ of $0.5-1 \mathrm{nM}$ $(10,24,25)$. Thus, okadaic acid and calyculin A can be used to characterize which type of phosphatase is involved in a particular physiological process (e.g., Refs. 26 and 27). In our experiments, calyculin A was approximately 100 -fold more potent than okadaic acid at stimulating $\mathrm{APP}^{\mathrm{S}}$ production (Figs. 2 and 3, Table 1). Thus, our data implicate a type 1 phosphatase in the control of $\mathrm{APP}^{\mathrm{S}}$ production. Furthermore, we have shown by immunoblotting that COS-1 cells express at least two of the known isoforms of PP1 (namely, PPl $\alpha$ and PPl $\gamma_{1}$ ), which exhibit very similar sensitivity profiles to okadaic acid, calyculin A and cantharidin (E. F. da Cruz e Silva et al., manuscript in preparation). Given the dynamic nature of the protein phosphorylation process, and given that PPI has been detected in all eukaryotic cells examined to date (including neurons and glia), it is likely that PPI also regulates $\mathrm{APP}^{S}$ production in other cell types. PPI has been shown to be particularly enriched in brain compared with peripheral tissues, and the occurrence and distribution of known PPl isoforms has been described in mammalian brain both by immunoblotting, immunocytochemistry, and in situ hybridization $(22,23)$.

Several neurotransmitters affect the physiological properties of neurons by regulating the phosphorylation state of PPI inhibitor proteins $(28-30)$, hence affecting PP1 activity. For example, dopamine, by increasing intracellular cAMP levels and activating protein kinase A, causes the phosphorylation and activation of the PP1 inhibitor DARPP-32 (dopamine- and cyclic AMP-regulated phosphoprotein, $M_{r}$ 32,000 daltons) in the medium-sized spiny neurons of the neostriatum $(28,31)$. Conversely, glutamate, by increasing intracellular calcium levels and activating PP2B, causes the dephosphorylation and inactivation of DARPP-32 (32). The convergence of major neurotransmitter pathways (e.g., dopaminergic, glutamatergic, and GABAergic) on PP1 suggests a critical role for this phosphatase in mediating the actions of these neurotransmitters.

Defects in signal transduction-dependent regulation of APP cleavage may play a critical role in the pathogenesis of AD. For instance, deficits in both neurotransmission $(33,34)$ and PKC activity (35-37) have been reported to be associated with $\mathrm{AD}$. Consistent with this notion, the stimulation of $\mathrm{APP}^{\mathrm{S}}$ release in response to neurotransmitters and other first messengers known to act via PKC has been reported in several studies (e.g., Refs. 38 and 39). The possibility now arises that regulation of APP metabolism, including APP ${ }^{\mathrm{S}}$ release and $\mathrm{A} \beta$ formation, may also be modulated by neurotransmitters or first messengers whose receptors are linked to modulation of PPl activity. The characterization of the protein kinases and phosphatases involved in the control of APP metabolism should facilitate the development of novel rational therapeutic intervention strategies for AD.

\section{ACKNOWLEDGMENTS}

We are grateful to Drs. J. D. Buxbaum, S. E. Gandy, and A. C. Nairn for critical reading of the manuscript. This work was supported by U. S. Public Health Service Grant AG-09464. CTBVZ was supported by a postdoctoral fellowship from $\mathrm{CNP}_{\mathrm{q}}$ and by PICD from Universidade Estadual de Londrina (Brazil). 


\section{REFERENCES}

1. Glenner GG, Wong CW. (1984) Alzheimer's disease: Initial report of the purification and characterization of a novel cerebrovascular amyloid protein. Biochem. Biophys. Res. Commun. 120: 885-890.

2. Caporaso GL, Gandy SE, Buxbaum JD, Ramabhadran TV, Greengard P. (1992) Protein phosphorylation regulates secretion of Alzheimer $\beta / A 4$ amyloid precursor protein. Proc. Natl. Acad. Sci. U.S.A. 89: 3055-3059.

3. Gillespie SL, Golde TE, Younkin SG. (1992) Secretory processing of the Alzheimer amyloid $\beta / A 4$ protein precursor is increased by protein phosphorylation. Biochem. Biophys. Res. Commun. 187: 1285-1290.

4. da Cruz e Silva OAB, Iverfeldt $\mathrm{K}$, Oltersdorf T, et al. (1993) Regulated cleavage of Alzheimer $\beta$-amyloid precursor protein in the absence of the cytoplasmic tail. Neuroscience 57: 873-877.

5. Hung AY, Selkoe DJ. (1994) Selective ectodomain phosphorylation and regulated cleavage of $\beta$-amyloid precursor protein. E.M.B.O. J. 13: 534-542.

6. Gandy SE, Czernik AJ, Greengard P. (1988) Phosphorylation of Alzheimer disease amyloid precursor protein peptide by protein kinase $\mathrm{C}$ and $\mathrm{Ca}^{2+} /$ calmodulin-dependent protein kinase II. Proc. Natl. Acad. Sci. U.S.A. 85: 6218-6221.

7. Suzuki T, Nairn AC, Gandy SE, Greengard P. (1992) Phosphorylation of Alzheimer amyloid precursor protein by protein kinase $C$. Neuroscience 48: 755-761.

8. Shenolikar S, Nairn AC. (1991) Protein phosphatases: Recent progress. Adv. Sec. Mess. Phosphoprot. Res. 23: 1-123.

9. da Cruz e Silva OB, da Cruz e Silva EF, Cohen PTW. (1988) Identification of a novel protein phosphatase catalytic subunit by cDNA cloning. F.E.B.S. Lett. 242: 106-110.

10. Ishihara $\mathrm{H}$, Martin $\mathrm{BL}, \mathrm{Brautigan} \mathrm{DL}$, et al. (1989) Calyculin A and okadaic acid: Inhibitors of protein phosphatase activity. Biochem. Biophys. Res. Commun. 159: 871-877.

11. da Cruz e Silva OAB, da Cruz e Silva EF, Greengard P. (1994) Role of protein phosphatase 1 in the metabolism of Alzheimer amyloid precursor protein. Soc. Neurosci. Abs. 20: 440 .

12. Weidemann A, Konig G, Bunke D, et al. (1989) Identification, biogenesis and local- ization of precursors of Alzheimer's disease A4 amyloid protein. Cell 57: 115-126.

13. Smith PK, Krohn RI, Hermanson GT, et al. (1985) Measurement of protein using bicinchoninic acid. Anal. Biochem. 150: 76-85.

14. Laemmli UK. (1970) Cleavage of structural proteins during the assembly of the head of bacteriophage T4. Nature 227: 680-685.

15. Buxbaum JD, Gandy SE, Cicchetti $P$, et al. (1990) Processing of Alzheimer $\beta /$ A4 amyloid precursor protein: Modulation by agents that regulate protein phosphorylation. Proc. Natl. Acad. Sci. U.S.A. 87: 6003-6006.

16. Wasco W, Bupp K, Magendantz M, Gusella JF, Tanzi RE, Solomon F. (1992) Identification of a mouse brain cDNA that encodes a protein related to the Alzheimer disease-associated amyloid beta protein precursor. Proc. Natl. Acad. Sci. U.S.A. 89: 10758-10762.

17. Wasco W, Gurubhagavatula S, Paradis MD, et al. (1993) Isolation and characterization of APLP2 encoding a homologue of the Alzheimer's associated amyloid beta protein precursor. Nature Genet. 5: 95-100.

18. Li YM, Casida JE. (1992) Cantharidin-binding protein: Identification as protein phosphatase 2A. Proc. Natl. Acad. Sci. U.S.A. 89: 11867-11870.

19. Li YM, Mackintosh C, Casida JE. (1993) Protein phosphatase $2 \mathrm{~A}$ and its $\left[{ }^{3} \mathrm{H}\right]$ canthari$\operatorname{din} /\left[{ }^{3} \mathrm{H}\right]$ endothall thioanhydride binding site. Inhibitor specificity of cantharidin and ATP analogues. Biochem. Pharmacol. 46: 1435-1443.

20. Sasaki K, Shima H, Kitagawa Y, Irino S, Sugimura T, Nagao M. (1990) Identification of members of the protein phosphatase 1 gene family in the rat and enhanced expression of protein phosphatase $1 \alpha$ gene in rat hepatocellular carcinomas. Jpn. J. Cancer Res. 81: 1272-1280.

21. da Cruz e Silva EF, Greengard P. (1995) Cloning of neuronal isoforms of protein phosphatase 1 by low-stringency screening of cDNA libraries. Neuroprotocols 6: 2-10.

22. da Cruz e Silva EF, Fox CA, Ouimet CC, Gustafson E, Watson SJ, Greengard P. (1995) Differential expression of protein phosphatase 1 isoforms in mammalian brain. J. Neuroscience 15: 3375-3389.

23. Ouimet CC, da Cruz e Silva EF, Greengard P. (1995) The $\alpha$ and $\gamma \mathrm{l}$ isoforms of protein phosphatase 1 are highly and specifically concentrated in dendritic spines. Proc. Natl. Acad. Sci. U.S.A. 92: 3396-3400. 
24. Hescheler J, Mieskes G, Ruegg JC, Takai A, Trautwein W. (1988) Effects of a protein phosphatase inhibitor, okadaic acid, on membrane currents of isolated guinea-pig cardiac myocytes. Pfluegers Arch. 412: 248252.

25. Bialojan C, Takai A. (1988) Inhibitory effect of a marine-sponge toxin, okadaic acid, on protein phosphatases. Specificity and kinetics. Biochem J. 256: 283-290.

26. Starke LC, Jennings ML. (1993) K-Cl cotransport in rabbit red cells: Further evidence for regulation by protein phosphatase type 1. Am. J. Physiol. 264: C118-C124.

27. Murata K, Sakon M, Kambayashi J, et al. (1993) The possible involvement of protein phosphatase 1 in thrombin-induced $\mathrm{Ca}^{2+}$ influx of human platelets. J. Cell. Biochem. 51: 442-445.

28. Walaas SI, Aswad DW, Greengard P. (1983) A dopamine- and cyclic AMP-regulated phosphoprotein enriched in dopamine-innervated brain regions. Nature 301: 69-71.

29. Snyder GL, Girault J-A, Chen JY, et al. (1992) Phosphorylation of DARPP-32 and protein phosphatase inhibitor-1 in rat choroid plexus: Regulation by factors other than dopamine. J. Neurosci. 12: 3071-3083.

30. Snyder G, Fisone G, Greengard P. (1994) Phosphorylation of DARPP-32 is regulated by GABA in rat striatum and substantia nigra. J. Neurochem. 63: 1766-1771.

31. Hemmings Jr HC, Greengard P, Tung HYL, Cohen P. (1984) DARPP-32, a dopamineregulated neuronal phosphoprotein, is a potent inhibitor of protein phosphatase-1. $\mathrm{Na}$ ture 310: 503-505.

Contributed by P. Greengard on April 21, 1995.
32. Halpain S, Girault J-A, Greengard P. (1990) Activation of NMDA receptors induces dephosphorylation of DARPP-32 in rat striatal slices. Nature 343: 369-372.

33. Davies P, Maloney AJF. (1976) Selective loss of central cholinergic neurons in Alzheimer's disease. Lancet 2: 1403.

34. Tomlinson BE, Corsellis JAN. (1984) Ageing and the dementias. In: Adams JH, Corsellis JAN, Duchen LW (eds). Greenfield's Neuropathology. 4th Ed. John Wiley \& Sons, New York, pp. 951-1025.

35. Cole G, Dobkins KR, Hansen LA, Terry RD, Saitoh T. (1988) Decreased levels of protein kinase $C$ in Alzheimer brain. Brain Res. 452: 165-174.

36. Van Huynh T, Cole G, Katzman R, Huang K-P, Saitoh T. (1989) Reduced protein kinase $\mathrm{C}$ immunoreactivity and altered protein phosphorylation in Alzheimer's disease fibroblasts. Arch. Neurol. 46: 1195-1 199.

37. Masliah E, Cole GM, Hansen LA, et al. (1991) Protein kinase $C$ alteration is an early biochemical marker in Alzheimer's disease. J. Neurosci. 11: 2759-2767.

38. Buxbaum JD, Oishi $M$, Chen HI, et al. (1992) Cholinergic agonists and interleukin 1 regulate processing and secretion of the Alzheimer $\beta / \mathrm{A} 4$ amyloid precursor protein. Proc. Natl. Acad. Sci. U.S.A. 89: 10075-10078.

39. Nitsch RM, Slack BE, Wurtman RJ, Growdon JH. (1992) Release of Alzheimer amyloid precursor derivatives stimulated by activation of muscarinic acetylcholine receptors. Science 258: 304-307. 